\title{
古代青銅鏡の腐食層内に潜伏する微生物の 検出とその同定
}

\author{
横 田＼cjkstart勝 1 \\ 栃原美佐子 ${ }^{2}$ \\ 田中正男 3 \\ 長柄毅 -1 \\ 三船 温 尚 $^{1}$ \\ 菅谷文則 4 \\ 宮 原 晋 - 5 \\ 清水康二
}

\author{
1富山大学芸術文化学部 \\ ${ }^{2} \mathrm{JFE}$ テクノリサーチ株式会社, 分析・評価事業部, 千葉事業所 \\ 3 千葉県産業支援技術研究所, 食品化学部 \\ 4 滋賀県立大学人間文化学部 \\ 5 奈良県立橿原考古学研究所調査第 1 課
}

J. Japan Inst. Metals, Vol. 72, No. 2 (2008), pp. 111-116

(C) 2008 The Japan Institute of Metals

\section{Detection and Identification of the Latent Microorganisms in the Corrosion Layers of Ancient Bronze Mirrors}

Masaru Yokota ${ }^{1}$, Misako Tochihara ${ }^{2}$, Masao Tanaka ${ }^{3}$, Takekazu Nagae ${ }^{1}$, Haruhisa Mifune ${ }^{1}$, Fuminori Sugaya ${ }^{4}$, Shinichi Miyahara ${ }^{5}$ and Yasuzi Shimizu ${ }^{5}$

${ }^{1}$ Faculty of Art and Design, University of Toyama, Takaoka 933-8588

${ }^{2}$ Analysis \& Characterization Division, Chiba Works, JFE Techno-Research Corporation, Chiba 260-0835

${ }^{3}$ Food and chemistry department, Chiba Industrial Technology Research Institute, Chiba 264-0017

${ }^{4}$ School of Human Cultures, The University of Shiga Prefecture, Hikone 522-8533

${ }^{5} 1$ st Dept. Researc, Archaeological Institute of Kashihara, Kashihara 634-0065

On an ancient bronze mirror, we carried out a scanning electron microscopic (SEM) examination of fractured corrosion layers, a biological microscopic observation of a gram-stained sample and DNA analyses of the samples removed from corroded sites.

From these scientific and technical researches, we obtained the following results.

Fine particles about $2 \mu \mathrm{m}$ in length were confirmed in the corrosion layer by the SEM observation. Microorganisms of the same size were observed in the gram-stained sample removed from the corrosion layer through a biological microscope. From these results, fine particles observed under the SEM should be considered as microorganisms. A lot of fine particles were confirmed especially in the corroded sites by the SEM observation. So (certain kinds of) microorganisms may have played a role in the corrosion (deterioration) of the ancient bronze mirrors while the mirrors were buried in soil.

From the base sequences obtained by DGGE analysis, two kinds of microorganisms were confirmed to exist in the corrosion layer of the ancient bronze mirror. One is $97.4 \%$ homologous to the $16 \mathrm{~S}$ rDNA of the uncultured bacterium (Accession number: AY 053488). It was also highly homologous to the sequence derived from the $16 \mathrm{~S}$ rDNA of the Xanthomonadaceae family such as Stenotrophomonas and Xanthomona. That is, the sequence is derived from a strain belonging to the Xanthomonadaceae family. The other base sequence is $97.4 \%$ homologous to the $16 \mathrm{~S} \mathrm{rDNA}$ of the Bacteroidales order such as uncultured Bacteroidales bacterium (Accession number: AY 859647). That is, the sequence is derived from a strain belonging to the Bacteroidales order.

Genes of microorganisms, presumed to belong to the Acetobacter, Gluconacetobacter genuses and Fe(III)-reducing bacterium, Shewanella algae were detected from the base sequence analysis by cloning.

From the results above, microbial activity is assumed to be high around the ancient bronze mirrors. The corrosion mechanism of bronze mirrors seems complicated, but a several types of microbes which possibly corrode bronze mirrors were verified.

(Received October 17, 2007; Accepted November 26, 2007)

Keywords: ancient bronze mirror, corrosion in clay, deterioration of metallic cultural resource, scientific investigation, microorganism, DNA analysis, DNA cloning

\section{1. 緒言}

筆者らはこれまで，材料学的視点から古代青銅鏡の調査を 行ってきた.この調査の過程で, 土中に埋蔵されていた古代 青銅鏡に，土中腐食とみられる事象を確認した。この腐食層
とみられる変質層の発生機構については, 実に長い歳月の上 に成り立っているため, 簡単には明らかにすることはできな いと思われる. しかしながら, 考えられるいくつかの仮説の うち, 著者らは, 微生物が関与したとみられる可能性を示唆 する科学的事象を確認した ${ }^{1-3)}$. 現在のところ, 青銅鏡の土 中に打痏食と微生物との直接的な立証には至っていない 
が，青銅鏡の腐食層とみられる変質層から採取した試料中に 数種類の微生物の存在が示唆される調査結果を得たのでこれ を報告する。

\section{2. 調査試料ならびに調査方法}

\section{1 調査試料}

調査を行った青銅鏡の全体写真は Fig. 1 に示すとおりで あり，(a)は鏡背側，（b）は鏡面側の写真である。この鏡は 盤龍鏡と称し，製造年代は中国・後漢末から西晋時代と考え られる。なお，出自は不明である，調査・分析試料の採取箇 所は鏡縁部とし，幅約 $5 \mathrm{~mm}$ ，鏡の中心部に向かって深さ約 $10 \mathrm{~mm}$ の小片を切り出した. この小片をさらに分割し, そ の一部はこれをさらに破断し, 走査型電子顕微鏡観察用に, さらにその残部をグラム染色による生物顕微鏡観察ならびに DNA 分析に供した.

\section{2 走査型電子顕微鏡による青銅鏡腐食層破面の観察}

青銅鏡の腐食層を中心とした破断面の観察には走査型電子 顕微鏡 $(J E O L$ 社製，JSM-5900LV)を用いた。測定条件は， 加速電圧 : $15 \mathrm{kV}$, 照射電流：約 $1.0 \mathrm{nA}$ である.なお，破 断面の観察に先駆けて，試料を破断した後，直ちにイオンス パッター法(使用装置; シンユー電子 $\mathrm{KK}$ 製，イオンスパッ ター装置，SC-701MCY)により金蒸着を行った。

\section{3 グラム染色による微生物の形態観察}

グラム染色による微生物の形態観察を行った．先ず，検体 を TE バッファー(10 mM Tris-HCl[pH 9.0], 1 mM EDTA) に浸漬し，滅菌済み歯ブラシで洗浄した。 TEバッファーで 洗浄した検体の表面を，新しい金属面が見える程度まで滅菌 済み棒やすりで削り，外表面の皮一枚程度を取り除いた。表 面を取り除いた検体を $70 \%$ エタノールに浸漬し，滅菌済み 歯ブラシで表層に付着する金属粉を洗浄・除菌した。さら に，洗浄した検体表面をバーナーで軽く焙る程度に滅菌し た。滅菌後，検体を滅菌済みペンチで 2 つに折り，検体内 部を露出させた。露出した断面の表面を滅菌済みのメスでか き取り，これを生理食塩水に懸濁した。懸濁物に対しグラム 染色を実施し, 微生物の有無を確認した. 観察には生物顕微 鏡(オリンパス光学 $\mathrm{KK} ， \mathrm{BX} 50 \mathrm{~F} 4)$ を使用した．生物顕微鏡

(a)

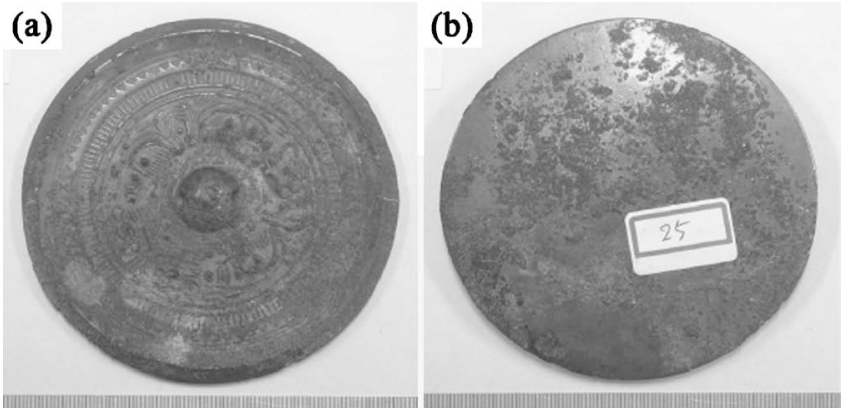

Fig. 1 Appearances of the ancient bronze mirror investigated in the present research.
による観察以外の作業は全てセーフティキャビネット内で無 菌的に実施した。

\subsection{DNA 分析}

DNA 分析に関しては, DGGE 解析法とクローニングによ る手法の 2 つの方法で行った。 各々の試料前処理方法, DNA 抽出方法, PCR 条件等を次に示す.

\subsubsection{DGGE 解析法による DNA 分析}

\section{(1) 試料の前処理}

検体を TE バッファー $\left(10 \mathrm{~mol} / \mathrm{m}^{3} \quad\right.$ Tris- $\mathrm{HCl}[\mathrm{pH} 9.0], \quad 1$ $\left.\mathrm{mol} / \mathrm{m}^{3} \quad \mathrm{EDTA}\right)$ に浸漬し, 滅菌済み歯ブラシで洗浄した. TEバッファーで洗浄した検体の表面を新しい金属面が見え る程度まで滅菌済み棒やすりで削り，外表面の皮一枚程度を 取り除いた。外表面を取り除いた検体を $70 \%$ エタノールに 浸漬し，滅菌済み歯ブラシで表層に付着する金属粉を洗浄す るとともに除菌した。洗浄した検体を滅菌済ペンチと滅菌済 み乳鉢，乳棒を用いて細かく粉砕した。

\section{(2) DNA の抽出}

前項で調製した検体を $4 \mathrm{~mL}$ の抽出バッファー $(100 \mathrm{~mol} /$ $\mathrm{m}^{3}$ Tris-HCl[pH 9.0], $50 \mathrm{~mol} / \mathrm{m}^{3}$ EDTA)に懸濁した。懸濁 液に TE 飽和フェノールを加え，フェノール法により DNA を抽出した。抽出したDNA はエタノール沈殿により濃縮 し，狭雑物を取り除くため，GFX ${ }^{\mathrm{TM}}$ Genomic Blood Purification Kit (Amersham Pharmacia Biotech, NJ, USA)により 精製を行った.

\section{（3） 16S rDNA 断片の PCR 増幅}

抽出した DNA を鋳型としてPCR 法により $16 \mathrm{~S}$ rDNA の 約 200 bp (E. coli No. 341-534)を増幅させた. 使用したプラ イマー4)を Table 1 に示す. DNA ポリメラーゼには AmpliTaq Gold (Applied Biosystems, CA, USA)，サーマルサイ クラーには GeneAmp PCR System 9600 (Applied Biosystems， CA，USA)を用いた．PCRの条件は，367K， $420 \mathrm{~s}+(367 \mathrm{~K}, 60 \mathrm{~s}, 208 \sim 318 \mathrm{~K}, 60 \mathrm{~s}, 201 \mathrm{~K}, 120 \mathrm{~s}) \times 20$ サイク ル $(2$ サイクル毎にアニーリング温度が $1 \mathrm{~K}$ 下がるように設 定 $)+(367 \mathrm{~K} ， 60 \mathrm{~s} 218 \mathrm{~K} ， 60 \mathrm{~s} 201 \mathrm{~K} ， 120 \mathrm{~s}) \times 15$ サイクル+ 345K，600s で行った.

PCR の条件を決定するために，鋳型 DNA 量および PCR 溶液中の $\mathrm{MgCl}_{2}$ 濃度の検討を行った.すなわち, 鋳型 DNA 量としては， $0.1 \mu \mathrm{L}, 1 \mu \mathrm{L}, 3 \mu \mathrm{L}$ あるいは $5 \mu \mathrm{L}$ を加え， $\mathrm{MgCl}_{2}$ 濃度として $1.5 \mathrm{~mol} / \mathrm{m}^{3}$ および $3.0 \mathrm{~mol} / \mathrm{m}^{3}$ の 2 種類 の濃度を添加した。

PCR により目的の配列が増幅されたことを確認するため に，2\%アガロースゲルによる PCR 産物の電気泳動を行っ た．具体的には，紫外線照射下でアガロースゲル中に電気泳 動された増幅断片とマーカーである 200 bp DNA Ladder(タ

Table 1 Primers used in the PCR amplification.

\begin{tabular}{lll}
\hline \multicolumn{1}{c}{ Primer } & & \multicolumn{1}{c}{ Nucleotide Sequence } \\
\hline GC-341f & Forward & $5^{\prime}$-GC clamp-CCTACGGGAGGCAGCAG-3' \\
$534 \mathrm{r}$ & Reverse & $5^{\prime}$-ATTACCGCGGCTGCTGG-3' \\
\hline
\end{tabular}

GC clamp; CGCCCGCCGCGCGCGGCGGGCGGGGCGGGGGCACGGGGGG 
カラバイオ，滋賀)を比較し，目的の長さと考えられる増幅 断片を確認し DGGE 解析の試料とした。

\section{（4）変性剂濃度勾配電気泳動(DGGE)の測定}

DGGE は Dcode DGGE コンプリートシステム(BIO RAD, CA, USA)を用いて行った．変性剤濃度勾配は電気泳動方向 に 30\%-60\%とし，ポリアクリルアミドゲル濃度は $10 \%$ と した．ゲル変性剤には尿素 $(\mathrm{BIO} \mathrm{RAD}, \mathrm{CA}, \mathrm{USA})$ とホルム アミド(BIO RAD，CA，USA)を用い, 泳動条件は電圧 200 $\mathrm{V}$ ，泳動時間 $12.6 \mathrm{ks}$ とした。

泳動後, 変性剂濃度勾配ゲルを SYBER Green（タカラバ イオ, 滋賀)で染色し, 染色された DNA が UV (310 nm) 照 射下で発する励起光を CCD カメラで撮影した.

\section{（5） DNA 断片の塩基配列解析}

DGGE 解析により得られたバンドをテンプレートとし, 16S rDNA の約 200 bp (Escherichia coli No. 341-534)を増 幅させた．使用したプライマー4) ある. DNA ポリメラーゼには AmpliTaq GoldTM(Applied Biosystems, CA， USA)，サーマルサイクラーには GeneAmp ${ }^{\circledR}$ PCR System 9600 (Applied Biosystems, CA, USA）を用いた. PCRの条件は 2.4.1(3)項で記述した内容と 同じである.

PCR 産物の増幅確認には $2 \%$ アガロースゲル電気泳動を 用いた。電気泳動後, 紫外線照射下でアガロースゲル中の増 幅断片とマーカー 100 bp DNA Ladder (タカラバイオ，滋 賀)を比較し, 目的の長さと考えられる増幅断片を確認し た。得られた PCR 産物を再度 2.4.1(4)項で述べた内容と同 様の方法で DGGE による泳動をし，バンドの純度を確認後 バンド部分のゲルを切り出した. このバンドをテンプレート とし, 上述の方法により再度 PCR を行い得られた産物を QIAquick $^{\circledR}$ PCR Purification Kit(QIAGEN, Hilden, Germany)を用いて精製し，塩基配列解析の試料とした.

精製した PCR 産物をテンプレートとし，シーケンシング 反応に供した.シーケンシング反応は ABI PRISM BigDye Terminator Kit (Applied Biosystems, CA, USA) と Table 2 に示したシーケンスプライマーを用い, GeneAmp PCR System 9600 (Applied Biosystems, CA, USA)上で行った. 反応 生成物は DyeEx ${ }^{\mathrm{TM}}$ 2.0 Spin Kit (QIAGEN, Hilden, Germany)を用いて精製し, ABI PRISM 3100 DNA Sequencer(Applied Biosystems, CA, USA)で配列解読を行った.

得られたバンドの配列と類似の塩基配列を国際塩基配列 データベース (GenBank/EMBL/DDBJ) から検索するため BLAST $^{5)}$ による相同性検索を行った.

Table 2 Primers used for the sequencing reaction.

\begin{tabular}{lcc}
\hline \multicolumn{1}{c}{ Primer } & $\begin{array}{c}\text { Direction- } \\
\text { ality }\end{array}$ & Nucleotide Sequence \\
\hline PCR Primer & & \\
GC-341f & Forward & 5'-GC Cramp-CCTACGGGAGGCAGCAG-3' \\
$534 \mathrm{r}$ & Reverse & $5^{\prime}$-ATTACCGCGGCTGCTGG-3' \\
\hline Sequence Primer & & \\
$341 \mathrm{f}$ & Forward & $5^{\prime}$-CCTACGGGAGGCAGCAG-3' \\
$534 \mathrm{r}$ & Reverse & $5^{\prime}$-ATTACCGCGGCTGCTGG-3' \\
\hline GC clamp; CGCCCGCCGCGCGCGGCGGGCGGGGCGGGGGCACGGGGGG \\
\hline
\end{tabular}

\subsection{2 クローニングによる DNA 分析}

\section{(1) 試料の前処理および微生物からの DNA 抽出}

遊星型ボールミル装置はフィリッチェ社製(ドイツ)遊星型 ボールミル P-5 を使用した. 滅菌したボールミル容器に約 $2.5 \mathrm{~g}$ の青銅鏡と約 $40 \mathrm{~m} \ell$ の $\mathrm{TE}$ 溶液を入れ，330 rpm, 2400 s で処理した. 処理後の TE 溶液をNo. 2 万紙およびポ アサイズ $0.8 \mu \mathrm{m}$ のフィルターを用いてろ過し， 万過溶液を $15,000 \mathrm{rpm}$ で $120 \mathrm{~s}$ 処理し上澄み液を捨て, 沈殿物を青銅鏡 表面菌とした．ただし，ここでの操作では青銅鏡は粉々にな っていなかった。

そこで，この青銅鏡を $70 \%$ エタノール溶液に 60 s 浸漬 し, 滅菌水で洗浄後, 滅菌済みのペンチ等を使用して青銅鏡 を砕いた後, ボールミル容器に約 $2 \mathrm{~g}$ の砕いた青銅鏡と約 $40 \mathrm{~m} \ell$ の TE 溶液を入れ, $330 \mathrm{rpm}, 900 \mathrm{~s}$ で粉砕処理した. 処理後の TE 溶液を表面菌と同様に遠心して得た沈殿物を青 銅鏡付着菌とした.

次に，青銅鏡表面菌抢よび青銅鏡付着菌からの DNA 抽出 を侏キアゲン社製の DNeasy Blood and Tissue kitsを使用し て行った.なお, DNA 抽出キット使用にあたりキット内添 付のグラム陽性菌の前処理を行った. 更に, 得られた DNA 溶液をエタノール沈殿により沈殿させ滅菌水で $15 \mu \mathrm{l}$ とした.

\section{(2) 抽出 DNA 断片の PCR 反応}

PCR 装置は MJ Research 社製の PTC-200を使用した。 反応系は全体を $20 \mu \ell$ とし, $2 \mu \ell 10 \times$ Buffer, $1.6 \mu \ell \mathrm{dNTP}$ Mixture $\left(2.5 \mathrm{~mol} / \mathrm{m}^{3}\right), \quad 0.8 \mu \ell \mathrm{MgSO}_{4}, \quad 0.4 \mu \ell$ Forward Primer, $0.4 \mu \ell$ Reverse Primer, $1.0 \mu \ell$ Template DNA, $13.72 \mu \ell \mathrm{H}_{2} 0,0.08 \mu \ell$ Platinum Taq DNA High Fidelity とし た。 な, 条件は, 変性を $367 \mathrm{~K} て ゙ 30 \mathrm{~s}$ ，アニーリングを $328 \mathrm{~K}$ で $30 \mathrm{~s}$, 伸長反応を $341 \mathrm{~K}$ で $90 \mathrm{~s}$ を サイクルとし て 35 サイクルさせた.

なお，原核生物 (16S-rDNA) 増幅用プライマーとして, 27f : 5'AGAGTTTGATCMTGGCTCAG 3' 1492r : 5'TACGGYTACCTTGTTACGACTT 3'

古細菌増幅用プライマーとして，2 組のプライマーセッ ト6,7)を用いた。

8F-N : 5' GGATCCAGACTTTGATYMTGGCTCAN 3' 907R-N : 5'CCGTCAATTCMTTTGAGTTN 3' および Ar3F : 5'TTCCGGTTGATCCTGCCGGA 3' AR927R : 5'CCCGCCAATTCCTTTAAGTTTC 3'を使用し た.

\section{(3) クローニング}

常法により 2.4.2(2)項で得られた PCR 産物を電気泳動に より確認し, PCR 産物を回収, T-Vector に連結させ, 大腸 菌 DH5 $\alpha$ に形質転換させた. 挿入遺伝子の有無の確認につ いてはコロニーダイレクト PCRにより確認を行った。そし て, 挿入遺伝子が確認できた大腸菌について, 液体培養を行 い, BIO-RAD 社製の Quantum Prep Plasmid Miniprep kit を使用しプラスミドを得た。

\section{（4）シークェンス反応およびシークェンス}

シークエンス反応は MJ Research 社製の PTC-200 を使 用した。 また，シークエンスは BECKMAN COULTER CEQ8000を使用した。なお，シークエンス反応条件および 
シークエンス条件については，BECKMAN COULTER CEQ8000 添付のプロトコールに準じて行った.

2.4.2(3)項で得られた挿入遺伝子を含むプラスミドについ て, シークエンス反応を行い, その後シークエンサーにて挿 入遺伝子の調査を行った. なお，シークエンス反応には下記 のユニバーサルプライマーを用いた.

\section{7f : 5’AGAGTTTGATCMTGGCTCAG 3' \\ 1492r : 5'TACGGYTACCTTGTTACGACTT 3 \\ 519r : 5'GWATTACCGCGGCKGCTG 3' \\ 530f : 5'GTGCCAGCMGCCGCGG 3' \\ 1100r : 5'GGGTTGCGCTCGTTG 3' \\ 1492r : 5'TACGGYTACCTTGTTACGACTT 3'}

\section{3. 調査結果ならびに考察}

\section{1 形態観察}

青銅鏡の腐食層表面部とその直下部分における破断面につ いて SEM により 2 次電子線像観察を行った. 得られた結果 をFig. 2 に示す.Fig. 2 (a) に示すように，腐食層表面部と 腐食されていない鏡体の境界部で白色の微生物のようにみら れる微粒子がいくつか観察される. ここで観察される微粒子 の形状はいずれも類似しており，長さは約 $2 \mu \mathrm{m}$ である。腐
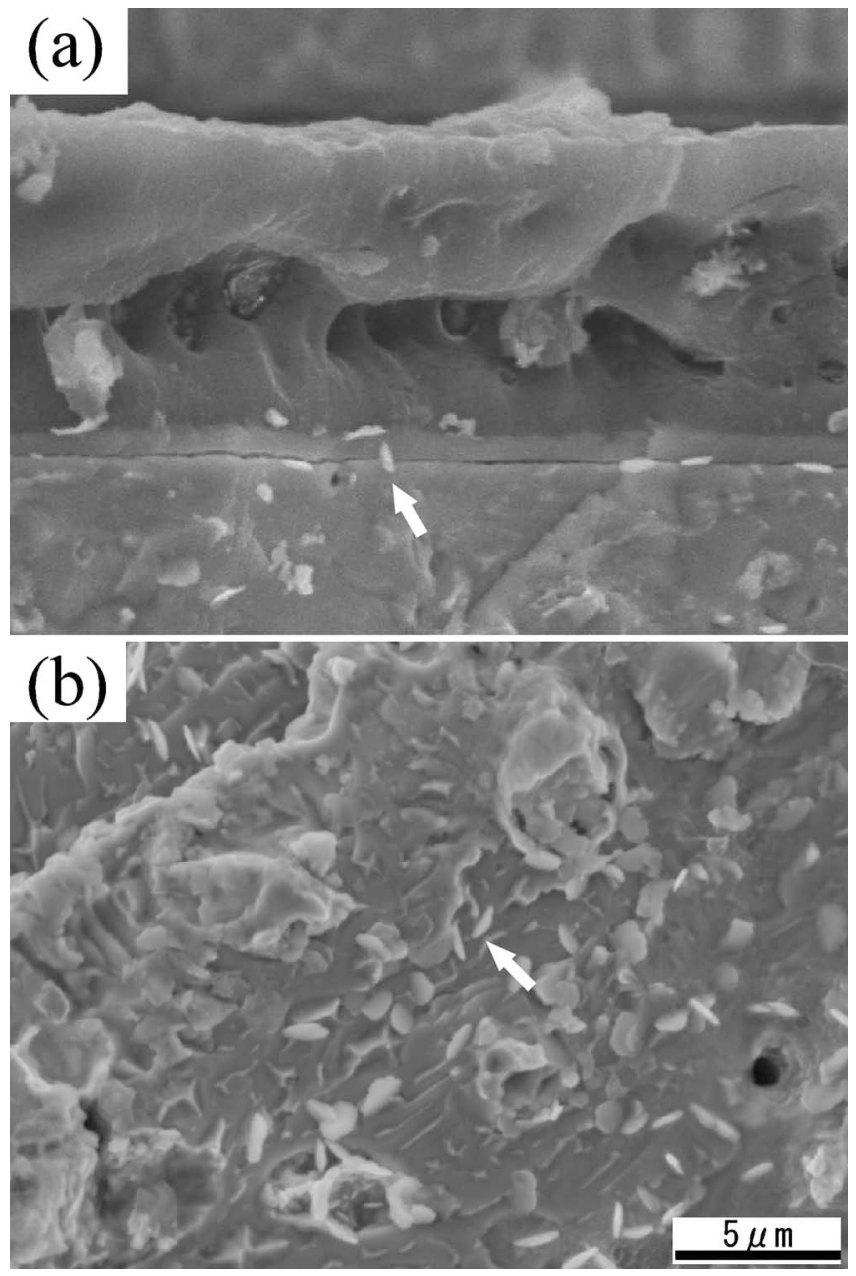

Fig. 2 Bacillary particulates observed in the corrosion layer of ancient bronze mirror.
食層内部など試料の別の部分では同様の微粒子が多数存在す ることが確認できる(Fig. 2(b))。一方，観察される微粒子 の大きさはいずれの微粒子とも長さが同じく $2 \mu \mathrm{m}$ 程度であ るが，幅は太いものと細いものの 2 種類が観察される．形 状が扁平なものであれば 1 種類の微生物とも考えられる. これらの白色物体は大きさや形状から微生物である可能性が 高いのではないかとみられる。そこで，腐食層から回収した 試料をグラム染色し, 微生物の確認を行った. 生物顕微鏡に よる形態観察した結果を Fig. 3 に示す。この結果から，グ ラム染色陽性の長さが約 $2 \mu \mathrm{m}$ の桿状細菌が観察され，腐食 層部に微生物が存在することが確認できた．大きさや形状は， SEM 観察により確認できた微粒子の一部に比較的類似して いることから，SEM で観察された微粒子が微生物である可 能性があるとみられる.

\section{$3.2 \mathrm{DNA}$ 分析}

\subsubsection{DGGE 解析法による結果}

鋳型 DNA 量 $\mathrm{MgCl}_{2}$ 濃度 $\left(1.5 \mathrm{~mol} / \mathrm{m}^{3}\right.$ および $\left.3.0 \mathrm{~mol} / \mathrm{m}^{3}\right)$ の各組み合わせについて PCR 条件を検討し，その検討結果 から, 鋳型 DNA 量 $3 \mu \ell, \mathrm{MgCl}_{2}$ 濃度 $3.0 \mathrm{~mol} / \mathrm{m}^{3}$ の条件で 増幅産物が認められた。 そこでこの条件を採用し，この条件 による PCR 増幅産物を用いた DGGE 法による電気泳動を 行い,ここで得られた電気泳動像を Fig. 4 に示す。この図 から明らかなように，2 本のバンドが確認できたことから， 2 種類の微生物が存在すると考えられる。この 2 種類のバン ドを各々回収し，バンド (a)，バンド(b) とした。これらの 塩基配列を調べ，相同性検索の結果とこれから推定される微 生物の属性は次の通りである.

バンド (a)から得られた塩基配列は uncultured bacterium （アクセッション番号 AY 053488)の 16S rDNA に対し相同 率 $97.4 \%$ を示した。この他に得られた相同率の高い配列は Stenotrophomonas, Xanthomonas など Xanthomonadaceae 科 の $16 \mathrm{~S}$ rDNA に由来する配列であった．従って，バンド (a) はXanthomonadaceae 科に帰属する菌株に由来する配列と考 えられる。

バンド (b)から得られた塩基配列は uncultured Bacteroi-

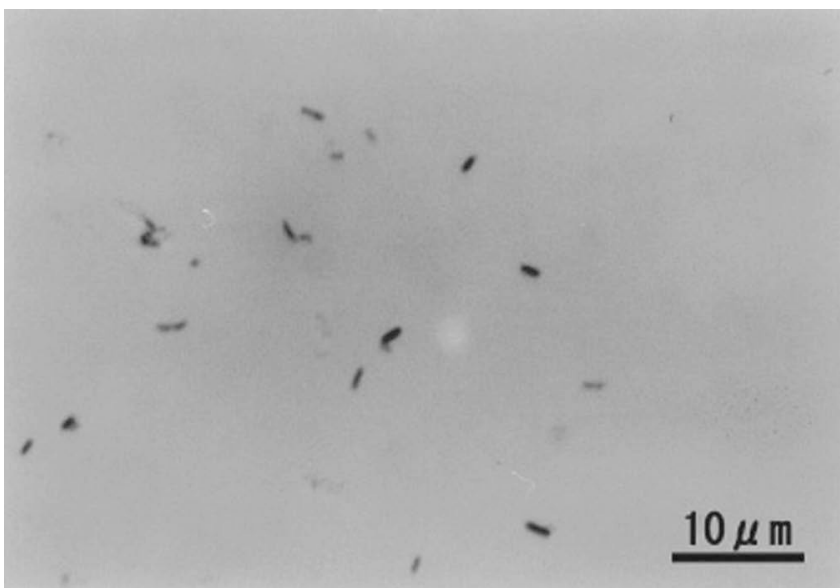

Fig. 3 Gram-stained image of the sample extracted from the corrosion layer of ancient bronze mirror. 


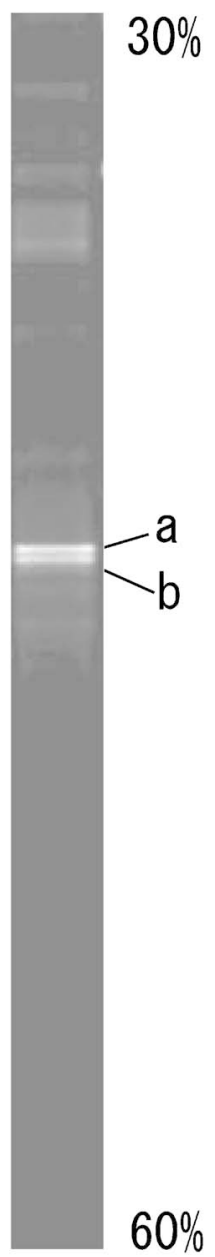

Fig. 4 DGGE electrophoretic image obtained from the PCR amplified product.

dales bactrium (アクセッション番号 AY 859647)など Bacteroidales 目の $16 \mathrm{~S}$ rDNA に対し相同率 $97.4 \%$ を示した。従 って，バンド(b)は, Bacteroidales 目に帰属する菌株に由来 する配列と考えらる。

な打，本報告の分類体系は基本的に BERGEY'S MANUALR ${ }^{R}$ OF SYSTEMATIC BACTERIOLOGY, SECOND EDITION に従っている8). 本文中で標記されている 一部の分類群については本書では提唱されているものの, 国 際細菌命名規約に基づいて承認されている正式な学名ではな いことを付記する.

\subsection{2 青銅鏡表面菌由来 DNA による PCR}

青銅鏡表面菌由来 DNA による PCR の結果, Fig. 5 (a)に 示したように原核生物の $16 \mathrm{~S}$ rDNA 増幅用プライマー $27 \mathrm{f}$ および $1492 \mathrm{r}$ を使用したときに PCR 産物が確認できた。そ こで,この PCR 産物の DNA 断片を回収しクローニングし た。

しかしながら, 古細菌増幅用プライマー $8 \mathrm{~F}-\mathrm{N}, 907 \mathrm{R}-\mathrm{N}$ および Ar3F， AR927r を使用したときでは PCR 産物を確 認できなかった (Fig. 5(b))。 そのため，古細菌は存在しな いと推定された.

\subsection{3 青銅鏡付着菌由来 DNA による PCR}

青銅鏡付着菌由来 DNA による PCR の結果, 青銅鏡表面 菌由来 DNA による PCR 結果と同様に Fig. 6 に示したよう (a)

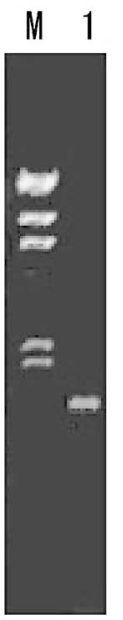

(b)

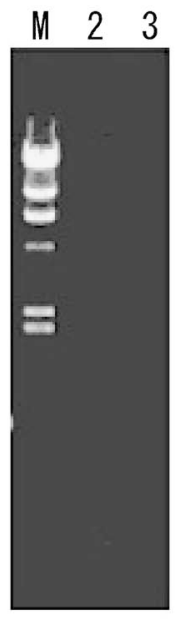

$\mathrm{M}: \lambda$-Hin $\mathrm{dIII} /$ digest, 1: Primer 27f and 1492r, 2: Primer 8 F-N and 907R-N 3: Primer Ar3f and Ar927r

Fig. 5 Electrophoresis of PCR- amplified DNA derived from the bacteria adhered on the surface of ancient bronze mirror.

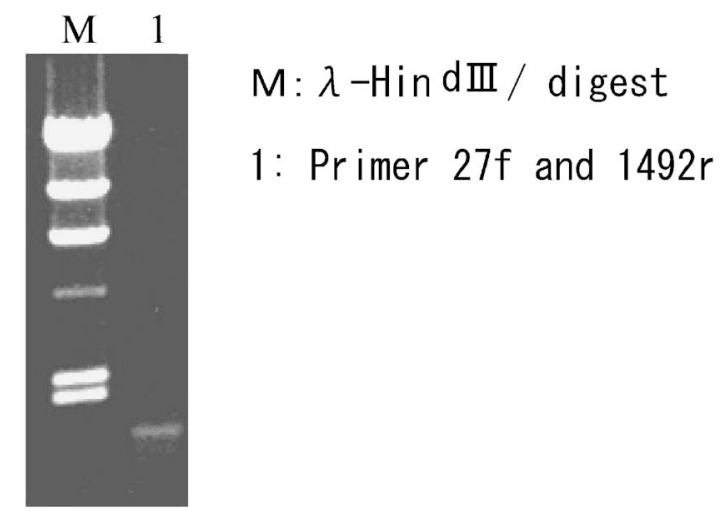

Fig. 6 Electrophoresis of PCR- amplified DNA derived from the latent bacteria in the ancient bronze mirror.

にプライマー $27 \mathrm{f}$ および $1492 \mathrm{r}$ を使用したときに PCR 産物 が確認できた。しかしながら今回も青銅鏡表面菌由来 DNA による PCR 結果と同様に，プライマー 8F-N，907R-N お よび Ar3F，AR927r を使用したときでは PCR 産物を確認 できなかった．次に，PCR 産物が確認できた DNA 断片を ゲルから回収し, pT7Blue T-Vectorに挿入して大腸菌 DH $5 \alpha$ を形質転換して, 約 60 個のクローンを得た. そして, 16 個のクローンについてシークエンス反応を行い，シーク エンサーにて挿入遺伝子の調査を行った。

\section{3 塩基配列および推定菌種}

クローニングによる塩基配列を調査した結果, 青銅鏡の表 面抢よび内部からは, 共通して, Acetobacter 属や Gluconacetobacter 属と推定させた微生物の遺伝子が検出され た.また，16S rDNA の 100-200bp しか解析できなかった 6 クローンは, Fe (III) 還元細菌 Shewanella algae と推定され た。

今回の DGGE 法, クローニング法により塩基配列が確認 できた微生物に加え, 著者らが, 本実験に先駆けて行った青 銅鏡付着菌の分析結果を Table 3 にまとめる ${ }^{9)}$. これらの結 果からわかるように, SEM 観察では 1 種類或いは 2 種類程 
Table 3 Results of microbiological analyses presented in the previous work ${ }^{9)}$

\begin{tabular}{cl}
\hline Pattern & Bacteria (Bracketed matters denote isolation.) \\
\hline A & $\begin{array}{l}\text { Phenanthrene degrading bacterium, Massilia, } \beta \text {-Proteobacteri- } \\
\text { um, J. anthinobacterium, Oxalobacter }\end{array}$ \\
\hline B & $\begin{array}{l}\text { Bacteroidetes bacterium, CFBgroup bacterium, Flabobacter } \\
\text { (Agricultural soil), (Gold ore) }\end{array}$ \\
\hline C & $\begin{array}{l}\text { Eubacterium, Green sulphur bacterium, Chlorobibacterium } \\
\text { (Soil) }\end{array}$ \\
\hline D & Ochrobactrum, $\alpha$-Proteobacterium \\
\hline E & $\begin{array}{l}\text { Ruminococcus, Palustris, Lactsphaera, Enterococcus, Vagococ- } \\
\text { cus, Trichococcus (Plant food for breeding) }\end{array}$ \\
\hline F & Green non-sulphur bacterium, Kouleothrix (Soil) \\
\hline
\end{tabular}

度とみていたが，実際には，古代青銅鏡には多くの微生物が 付着或いは侵入していることがわかる.

著者らがこれまでに分析した微生物の大部分は, 出土され た土壌由来の微生物とみられ, 出土の点からも大变興味深 い.これら微生物のうち, 特徵的な働きの報告がある微生物 に着目すると, 二酸化炭素・硫化水素酸性環境下で光合成独 立栄養的に生育する緑色硫黄細菌 (Chlorobiaceae), 窒素酸化 物を利用してこれらを還元してガス状生産物を発生させる脱 窒菌 (Flavobacter), エタノールから酢酸・グルコースからグ ルコン酸を生成する酢酸菌 (Acetobacter, Gluconobacter), 堆 肥中などに生息してギ酸・乳酸・酢酸などを生産するセル ロース分解菌 (Eubacterium)などが挙げられる10)。ただし， 微生物の土中での作用は, 環境により変化するうえ, その働 きが明確になっていない微生物種も多いため，上述の働きが 必ずしも土中で起こっていたかは確かではない。しかしなが ら，これら多数の微生物が，青銅鏡を媒体として，相互に関 与しあって生息していたことは間違いない.しかも, いくつ かの働きのうちに生じる硫酸イオンや酢酸イオンなどは, 青 銅鏡の変質を招いた可能性は高い.このような反応機構につ いては, 単独種の微生物によるものではなく, 複数種が関与 しているとみられるため, 青銅鏡腐食(変質)のシミュレート 試験は難しいが，これを行うための菌株は複数培養で進めて いる.

以上本文で明記した微生物は相同性が高いものから記載し ているが，これら以外にも，相同性が比較的高いものについ て調べると，Thiobachillus 属などが挙げられる．Thiobachillus 属には硫黄酸化細菌や鉄酸化細菌などがあるが, これらは, 硫黄或いは無機硫黄化合物をエネルギー源とし, これらを酸化する働きがある11-13)。すなわち、これらの微 生物が活動すると, 硫酸が生成し, 周辺環境を酸性にするた め，青銅鏡腐食(変質)への関与は十分に考えられる.

\section{4. 結 論}

古代青銅鏡腐食層内部の走査型電子顕微鏡観察，腐食部位 から回収した試料のグラム染色後の生物顕微鏡観察および DNA 分析を行った結果から以下の知見を得た。

(1) 腐食部位の走査型電子顕微鏡 $(\mathrm{SEM})$ 観察により，長 さが約 $2 \mu \mathrm{m}$ の微粒子が観察された. さらに, この部位の試
料をグラム染色し, 生物顕微鏡で観察した結果, $2 \mu \mathrm{m}$ 程度 の微生物が確認できた。このことから, SEM で観察された 微粒子は微生物であるとみられる. また, 腐食(変質)部位に SEM では微粒子が特に多く観察されていることから, 青銅 鏡の腐食 (変質)には, 微生物が関与した可能性が高い.

(2) 今回の DGGE 解析による塩基配列から，2 種類の微 生物の存在が確認できた。 そのうちの 1 種類は, uncultured bacterium(アクセッション番号 AY 053488)の 16S rDNA に 対し相同率 $97.4 \%$ を示した。この他に得られた相同率の高 い配列は Stenotrophomonas, Xanthomonas な ぞ Xanthomonadaceae 科の $16 \mathrm{~S}$ rDNA に由来する配列であった。す なわち, Xanthomonadaceae 科に帰属する菌株に由来する配 列と考えられる.

2 種類目の塩基配列は uncultured Bacteroidales bactrium (アクセッション番号 AY 859647) など Bacteroidales 目の 16S rDNA に対し相同率 $97.4 \%$ を示した。 すなわち，Bacteroidales 目に帰属する菌株に由来する配列と考えられる.

（3）クローニングによる塩基配列から，Acetobacter 属や Gluconacetobacter 属, Fe (III)還元細菌 Shewanella algae と推 定できる微生物の遺伝子が見つかった.

以上の分析結果と知見ををとめると, 青銅鏡周辺は, 実に 微生物活性が高かったことが予想される.すなわち, 青銅鏡 の腐食には, 複雑な機構が関与しているとみられるが, 特に 青銅鏡を腐食させる可能性のある微生物を今回までに数種確 認することができた。

\section{文献}

1) M. Yokota, F. Sugaya, H. Mifune, Y. Kobori, K. Shimizu, K. Nakai, S. Miyahara and Y. Shimizu: J. Japan Inst. Metals 66 (2002) 708-714.

2) M. Yokota, F. Sugaya, H. Mihune, K. Shimizu, K. Nakai, S. Miyahara and Y. Shimizu: J. Japan Inst. Metals 66 (2002) 10301038.

3) M. Yokota, F. Sugaya, H. Mihune, K. Shimizu, K. Nakai, S. Miyahara and Y. Shimizu: Mater. Trans. JIM. 44(2003) 268276.

4) G. Muyzer, E. C. De Waal and A. G. Uitterlinden: Appl. Environ. Microbiol. 59(1993) 695-700.

5) S. F. Altschul, T. F. Madden, A. A. Schaffer, J. Zhang, W. Miller and D. J. Lipman: Nucleic Acids Res. 25 (1997) 33893402 .

6) Eitan Ben-Dov et al.: Appl. Environ. Microbiol. 72 (2006) 69026906

7) Brajesh K. Singh et al.: Appl. Environ. Microbiol. 72 (2006) 7278-7285

8) G. M. Garrity and J. G. Holt: Taxonomic Outline of the Archaea and Bacteria. In: Bergey's Manual of Systematic Bacteriology, 2nd ed., vol. 1 (The Archaea and the deeply branching and phototrophic Bacteria) (D. R. Boone and R. W. Castenholz, eds. (Springer-Verlag, New York, 2001).

9) M. Yokota, M. Tochihara, H. Mifune, F. Sugaya, Y. Shimizu, S. Miyahara, K. Nakai, Y. Kobori and K. Shimizu: Collected Abstracts of the 2004 Spring Meeting of the Japan Inst. Metals (2004) p. 448.

10) K. Yamasato, S. Udagawa, T. Kodama and T. Morichi: Separation method of microorganism, R \& D planning, 1986(facsimile edition; 2001).

11) Japan Society of Corrosion Engineering: Handbook of corrosion and corrosion prevention, Maruzen, 2003.

12) M. G. Dastidar, A. Malik and P. K. Roychoudhury: Energy Conversion \& Management 41 (2000) 375-388.

13) Y. Konishi, T. Kawamura and S. Asai: Journal of Chemical Engineering of Japan $\mathbf{2 6}$ (1993) 83-88. 